УДК 346.1., 347.72

М.О.Суханов

асистент кафедри інтелектуальної власності, інформаційного та корпоративного права Львівського національного університету імені Івана Франка

\title{
СУТНІСТЬ І ЗМІСТ КОРПОРАТИВНОГО ДОГОВОРУ ЯК ПІДСТАВИ НАБУТТЯ КОРПОРАТИВНИХ ПРАВ ТА ОБОВ'ЯЗКІВ УЧАСНИКА ТОВАРИСТВА 3 ОБМЕЖЕНОЮ ВІДПОВІДАЛЬНІСТЮ
}

Права й обов'язки учасника товариства з обмеженою відповідальністю (далі - ТОВ) визначаються як законодавством, так і окремими пунктами установчих документів і положень. Втім, окрім дотримання вищезазначених положень, корпоративне управління повинне забезпечити організацію взаємодії учасників щодо діяльності ТОВ, що можливо здійснювати через конструкцію корпоративного договору, спрямованого на визначення їх прав, обов'язків, порядку їх здійснення і відповідальності у цій сфері.

Загалом, корпоративний договір у правовій науці є відносно новим та недостатньо дослідженим явищем. Свою увагу вивченню корпоративного договору приділили такі дослідники, як В. Васильєва, І. Венедіктова, О. Вінник, Ю. Жорнокуй, О. Кібенко, Л. Сіщук, І. Спасибо-Фатєєва, В. Цікало, Ю. Юркевич, О. Яворська та ін. На дисертаційному рівні особливості корпоративного договору дослідила М. Сигидин, водночас слід зауважити, що це дослідження було проведене ще до прийняття Закону України «Про товариства з обмеженою та додатковою відповідальністю» .

Відповідно до ст. 7 Закону України «Про товариства з обмеженою та додатковою відповідальністю», корпоративний договір - це договір, за яким учасники товариства зобов'язуються реалізовувати свої права та повноваження певним чином або утримуватися від їх реалізації.

Право на укладення корпоративного договору передбачено у ст. 7 Закону України «Про товариства з обмеженою та додатковою відповідальністю» . Д. Журавлев, О. Коротюк, К. Чижмарь аналізуючи вищезазначену норму вирізняють наступні особливості корпоративного договору: корпоративний договір є безвідплатним; вчиняється у письмовій формі; в договорі мають бути зазначені дата укладення і строк дії; зміст корпоративного договору є конфіденційним і не підлягає розкриттю, якщо інше не встановлено законом чи договором; положення договору мають пріоритетне значення порівняно з укладеними його стороною іншими договорами, що суперечать положенням корпоративного договору (договір, укладений стороною корпоративного договору на порушення такого корпоративного договору, є нікчемним, якщо інша сторона за договором знала або мала знати про таке порушення); на виконання положень корпоративного договору може видаватися безвідклична довіреність; корпо- ративний договір може бути укладений виключно особами, які є учасниками товариства (фізичними та/або юридичними особами) [1, с. 27].

А. Свінцицький вважає, що корпоративний договір може бути укладений між учасниками товариства і кредиторами товариства [2]. 3 цим науковцем не можна погодитися, так як це суперечитиме ст. 7 Закону України «Про товариства з обмеженою та додатковою відповідальністю».

Зміст корпоративного договору складає сукупність умов, на яких він укладений. Водночас із корпоративного договору виникають правовідносини, змістом яких є права й обов'язки учасників, закріплені у ньому. Умови корпоративного договору регулюють поведінкові акти суб'єктів-учасників і знаходять юридичне вираження через їх права й обов'язки.

Відповідно до п. 5 ст. 7 Закону України «Про товариства з обмеженою та додатковою відповідальністю» зміст корпоративного договору не підлягає розкриттю і є конфіденційним, якщо інше не встановлено законом або договором. Щодо цієї норми Л. Сіщук цілком справедливо звертає увагу на те, що хоча зазначена норма має диспозитивний характер і дає можливість у договорі передбачити інше, але навряд чи це на практиці зумовить намір сторін розкрити зміст договору для інших учасників товариства в разі укладення корпоративного договору на першочергове задоволення інтересів кількох учасників чи певної групи учасників у відношенні до корпоративного інтересу товариства чи на шкоду інтересам товариства [3, с. 52-53].

Професор О. Яворська $з$ цього приводу зазначає, що домовленості, які фіксуються у корпоративному договорі, звичайно впливають на прийняття рішень вищим органом юридичної особи. А юридична особа позбавлена будь-якої можливості знати як про факт, так і про зміст укладеного договору. Безперечно, що зміст договору є конфіденційним для сторонніх до корпорації осіб. Але чи може він бути таким для інших учасників корпорації, які не взяли участь у такому договорі, та й для самої корпорації? [4, с. 289]. Відповідь на це питання має бути чіткою і спрямованою на можливість інформування всіх учасників товариства та самого ТОВ щодо факту укладення корпоративного договору, а у разі звернення таких суб'єктів корпоративного правовідношення до сторін корпоративного договору з вимогою про 
ознайомлення з його змістом, то й задоволення зазначених вимог. Що стосується третіх осіб, які не є учасниками ТОВ, то цілком справедливо, що зміст договору має бути конфіденційним, якщо інше не передбачено законом чи установчими документами TOВ. Зазначені положення варто було б відобразити у нормах нового Закону України «Про товариства з обмеженою та додатковою відповідальністю» .

Корпоративний договір, стороною якого є держава, територіальна громада, державне або комунальне підприємство чи юридична особа, у статутному капіталі якої 25 і більше відсотків прямо або опосередковано належить державі або територіальній громаді, оприлюднюється протягом 10 днів iз моменту його укладення шляхом розміщення на сайті відповідного органу державної влади, органу місцевого самоврядування [5].

При дослідженні змісту корпоративного договору необхідно приділити окрему увагу одній з його особливостей, що випливає з його багатосторонності - наявності в учасників договору спільної мети. Мета - обов'язковий атрибут багатостороннього договору. Якщо немає спільної мети, то немає і багатостороннього договору, а тому необхідно говорити про двосторонній (зустрічний) договір. Мета в багатосторонньому договорі може бути будь-якою, як майновою, так і немайновою, головне - вона повинна бути не заборонена законом і не суперечити основним засадам цивільного законодавства. О. Таран, досліджуючи питання спільної мети у багатосторонніх договорах, доходить висновку, що мета, поряд із предметом, є істотною умовою таких договорів [6, с. 91]

Відносячи до істотних умов корпоративного договору лише умову щодо предмету, вважаємо, що у разі укладення корпоративного договору учасникам ТОВ доцільно визначати його мету, зважаючи на те, що вони в процесі виконання умов договору об’єднують та координують свої зусилля для досягнення певного бажаного для них результату.

Укладаючи корпоративний договір, учасники ТОВ можуть керуватись різними мотивами та мати різні причини для вступу у договірні відносини, що породжуються таким договором. Однак, незважаючи на це, усі його учасники переслідують єдину та спільну мету, яка досягається шляхом здійснення ними узгодженої діяльності. Фактично, тут можна прослідкувати взаємообумовленість і взаємозалежність предмету корпоративного договору та спільної мети його учасників: мета, яку ставлять перед собою учасники корпоративного договору, може бути реалізована лише шляхом їх спільної діяльності з управління належними їм корпоративними правами, а природа та характер цього управління більшою мірою залежать від мети договору.

Якою конкретно є мета корпоративного договору, сказати досить важко, оскільки у кожному окремому випадку його укладення вона може відрізнятись. Проте із впевненістю можна стверджува- ти про те, що бажаним результатом, на досягнення якого укладається договір, є підвищення ефективності діяльності ТОВ, забезпечення довгострокового комерційного успіху, збільшення іï прибутків, а отже і збільшення прибутків учасників корпоративних прав. У зв'язку із цим, до умов, які доцільно узгоджувати при укладенні корпоративного договору, також належить і спільна мета учасників договору - учасників корпоративних відносин.

Корпоративний договір, яким встановлюється обов'язок учасників забезпечити голосування згідно 3 вказівками органів управління товариства, є нікчемним [5]. Ця норма призначена для унеможливлення маніпуляції процесами управління товариством і забезпечити право учасника на участь у товаристві на рівних правах з іншими. Однак, існуюче формулювання закону викликає суттєві зауваження. Зокрема, воно вказує на те, що нікчемним є договір, яким встановлюється обов'язок учасників забезпечити голосування згідно з вказівками тільки органів управління товариства, а не будь-яких інших органів та/або осіб. Такий підхід, як слушно зауважують Д. ЖАуравлев, О. Коротюк, К. Чижмарь, створює можливості для утворення положень корпоративного договору, що буде обмежувати права учасника (учасників) товариства. Для забезпечення згаданих прав учасника необхідним видається внесення змін до законодавчого формулювання і передбачення у ньому заборони включення до корпоративного договору положень, які б у будь-якій формі визначали обов'язок учасника голосувати не на власний розсуд, а згідно із вказівкою договору чи вказівкою будь-яких органів та/або осіб [1, с. 27-28].

Строк договору може бути обумовленим бажанням сторін укласти його на певний, необхідний для них період часу. У такому разі визначення строку договору як однієї з його умов є цілком виправданим і доцільним. Строк дії договору може визначатися сторонами, проте, не може тривати довше за існування корпоративних відносин; однак окремі обов'язки за договором можуть зберігатися і після припинення участі особи у товаристві (наприклад, обов'язок не розголошувати зміст корпоративного договору).

Також, строк корпоративного договору може обумовлюватись строком існування юридичної особи корпоративного типу, в межах якої він укладений. Із припиненням ТОВ відбувається й припинення договору.

Однак, з іншого боку, чинність корпоративного договору може бути прив'язана до досягнення спільної для учасників мети, якщо така опосередкована договором. У такій ситуації говорити про визначення строку корпоративного договору проблематично з урахуванням того, що досить складно вказати чіткий строк, протягом якого сторони досягнуть спільної мети. 
Враховуючи те, що корпоративний договір $є$ договором, за яким учасники товариства зобов'язуються реалізовувати свої права та повноваження певним чином або утримуватися від їх реалізації положення договору мають зобов'язальний характер щодо його сторін (учасників товариства) і не можуть створювати обов'язків для третіх осіб, котрі не є учасниками товариства.

Корпоративний договір врегульовує питання реалізації прав і повноважень учасників, визначених законом і статутом товариства, що може стосуватися: а) особливого порядку виконання повноважень чи реалізації прав; б) придбання або відчуження частки в статутному капіталі; в) порядку розподілу прибутку тощо.

Корпоративний договір може передбачати умови або порядок визначення умов, на яких учасник має право або зобов'язаний купити або продати частку у статутному капіталі (iї частину), а також визначати випадки, коли таке право або обов'язок виникає [5].

Щодо законодавчого закріплення переважних прав учасників юридичних осіб корпоративного типу, зокрема ТОВ та ТДВ, необхідно зазначити, що законодавець не залишив зазначене питання без уваги. Так, ст. 53 Закону України «Про товариства з обмеженою та додатковою відповідальністю" встановлює, що учасник ТОВ має право продати чи іншим чином відступити свою частку (ії частину) у статутному капіталі одному або кільком учасникам цього товариства. Відчуження учасником ТОВ своєї частки (ії частини) третім особам допускається, якщо інше не встановлено статутом товариства. Учасники товариства користуються переважним правом купівлі частки (ії частини) учасника пропорційно до розмірів своїх часток, якщо статутом товариства чи домовленістю між учасниками не встановлений інший порядок здійснення цього права.

Як вбачається, норми цих статей мають диспозитивний характер, оскільки встановлюють, що учасники ТОВ мають право, а не обов'язок відступити свою частку іншим учасникам цього ТОВ. Фактично це означає, що наявність переважних прав у разі відчуження частки та порядок їх реалізації можуть бути зумовлені у статуті або договорі між учасниками ТОВ. Такий висновок є цілком логічним, а дозвільна спрямованість норм, що регулюють питання переважних прав у межах діяльності ТОВ, $\mathrm{e}$ доцільною з огляду на те, що учасники ТОВ вправі самостійно реалізовувати свої права, у т.ч. й ті, що випливають із їх участі у діяльності ТОВ. Оскільки ТДВ за своїм статусом, порядком створення та діяльністю близьке до ТОВ, законодавець поширюе на ТДВ норми, що регулюють діяльність ТОВ, якщо інше не встановлене статутом товариства і законом.

Водночас варто також звернути увагу на те, що відповідно до ч. 8 ст. 20 Закону України «Про товариства з обмеженою та додатковою від- повідальністю» переважне право учасника товариства не застосовується у разі, якщо це передбачено корпоративним договором, стороною якого є такий учасник [5].

Проаналізувавши положення чинного законодавства, можна дійти висновку про відсутність чітких приписів щодо імперативного визначення вартості часток у статутному (складеному) капіталі юридичних осіб корпоративного типу. Отже, видається цілком можливим та таким, що не суперечить закону, право учасника юридичної особи корпоративного типу корпоративних прав самостійно визначати їхню вартість у разі відчуження таких прав, звичайно, з урахуванням ринкової вартості. 3 огляду на це, учасники корпоративного договору вправі також самостійно зумовлювати у договорі вартість корпоративних прав у випадку їх відчуження у майбутньому. Це питання не стосується безпосередньо відчуження корпоративних прав, адже, як неодноразово зазначалося, корпоративний договір носить немайновий характер і не опосередковує перехід права власності на корпоративні права, однак в силу того, що корпоративний договір укладається на спільне управління корпоративними правами, що належать учасникам юридичної особи корпоративного типу, видається, що узгоджене обумовлення вартості корпоративних прав у разі їх відчуження цілком підпадає під поняття «управління корпоративними правами» та може бути зазначене у корпоративному договорі.

О. Чебану зазначає, що в корпоративних договорах можна врегулювати певні потенційні корпоративні конфлікти i «тупикових ситуацій», які можуть виникати між учасниками ТОВ. Насамперед це стосується ситуацій, коли прийняття будь-якого рішення загальними зборами або наглядовою радою є неможливим через відмінності позицій учасників, які володіють однаковою кількістю голосів (50/50) [7, с. 436-437].

Учасники, укладаючи між собою корпоративний договір, не застраховані від настання тих чи інших об'єктивних чи суб'єктивних обставин, які можуть вплинути на виконання договірних зобов'язань або поставити під сумнів доцільність окремих умов договору. Тому, договірні правовідносини, які породжуються корпоративним договором, характеризуються динамічністю. Враховуючи це, цивільне законодавство надає можливість сторонам змінити зміст корпоративного договору відповідно до обставин, які настали внаслідок спільного узгодження та схвалення змін або в судовому порядку у разі істотного порушення договірних зобов'язань однією з сторін договору.

Загалом, на динаміку корпоративного договору можуть впливати як внутрішні фактори (характер відносин між учасниками договору, невиконання однією із сторін своїх зобов'язань, відмова 
сторони від виконання договору), так і зовнішні фактори (розвиток економіки, зміни законодавства). Кожна із перелічених обставин може вносити корективи у порядок виконання сторонами своïх зобов' язань, а також зумовлювати необхідність зміни відповідних договірних відносин.

Отже, не дивлячись на деякі дискусійні моменти щодо корпоративного договору його закріплення в Законі України «Про товариства з обмеженою та додатковою відповідальністю» $€$ позитивним кроком законодавця, який спрямований на покращення атмосфери в корпоративних товариствах, створення ефективних засобів впливу його учасників на корпоративне управління та на запобігання можливих зловживань корпоративними правами у цій сфері.

\section{Iimepamypa}

1. Товариство з обмеженою відповідальністю за новим Законом: узагальнення законодавства, коментарі, зразки документів / Д.В. Журавлев, О.В. Коротюк, К.І. Чижмарь. Київ : ОВК, 2019. 64 с.

2. Свінцицький А. Корпоративні договори: нові можливості та старі проблеми URL: letrado.ua/uk/publikatsiyi/korporatyvni-dohovory/.

3. Сіщук Л. Новели законодавства щодо корпоративного договору. Підприєлниитво, господарство іправо. 2018. № 10. С. 49-54.

4. Яворська О.С. Корпоративний договір у механізмі корпоративного управління. Адаптація корпо ративного законодавства Украӥни до права Європейського Союзу: збірник наукових праць за матеріалали Міжнародної науково-практичної конферениї̈ / за ред. В.В. Луця. Івано-Франківськ, 2016. С. 286-289.

5. Закон України «Про товариства з обмеженою та додатковою відповідальністю» від 06 лютого 2018 р. URL: https://zakon.rada.gov.ua/laws /show/2275-19.

6. Бабецька I.Я. Здійснення та захист переважних прав в корпоративних правовідносинах : дис. ... канд. юрид. наук : 12.00.03. Київ, 2013. 218 с.

7. Чебану O.P. Корпоративні договори у правовій системі України. Збірник тез доповідей студентів, аспі рантів та з добувачів-учасників 74-ї звітної конферениї Одеського національного університет у імені I.I. Мечникова. Секиія економічних і правових наук (Одеса, 2527 квітня 2018 р.). Одеса : Фенікс, 2018. С. 436-437.

\section{Анотація}

Суханов М. О. Сутність і зміст корпоративного договору як підстави набуття корпоративних прав та обов'язків учасника товариства 3 обмеженою відповідальністю. - Стаття.

У статті розглянуто сутність та особливості корпоративного договору як підстави набуття корпоративних прав та обов'язків учасника товариства з обмеженою відповідальністю.

На підставі наукових положень і враховуючи норми чинного законодавства визначено такі ознаки корпоративного договору як: безвідплатність; письмова форма; конфіденційність змісту корпоративного договору; пріоритетність положень корпоративного договору над іншими договорами товариства; сторонами договору є лише учасники товариства. Звернуто увагу на умови, за яких корпоративний договір є нікчемним.

Охарактеризовано мету та мотиви укладення корпоративного договору учасниками товариства з обмеже- ною відповідальністю. Окрему увагу приділено розгляду питання щодо строку дії та чинності корпоративного договору. Проаналізовано особливості закріплення переважних прав учасників товариства з обмеженою відповідальністю у змісті корпоративного договору. Досліджено інші істотні умови корпоративного договору. Визначено дискусійні моменти щодо конфіденційності корпоративного договору та запропоновано способи ïx подолання. Розглянуто особливості оприлюднення корпоративного договору, стороною якого є держава, територіальна громада, державне або комунальне підприємство чи юридична особа.

Доведено, що договірні правовідносини, які породжуються корпоративним договором, характеризуються динамічністю, тому учасникам товариства 3 обмеженою відповідальністю (сторонам договору), у визначених законодавством випадках, надається право змінювати зміст корпоративного договору. Визначено позитивні моменти закріплення корпоративного договору у новому Законі України «Про товариства з обмеженою та додатковою відповідальністю» .

Ключові слова: товариство з обмеженою відповідальністю, корпоративні права, корпоративний договір, учасники корпоративного договору, строк дії корпоративного договору, конфіденційність корпоративного договору.

\section{Summary}

Sukhanov M. O. The essence and content of the corporate agreement as the basis for acquiring corporate rights and obligations of a member of a limited liability company. -Article.

The essence and features of the corporate agreement as the basis for acquiring corporate rights and obligations of the member of a limited liability company are considered. Based on the scientific regulations and taking into account the norms of the current legislation, the following features of the corporate agreement are defined as: non-payment; written form; confidentiality of the content of the corporate agreement; priority of the provisions of the corporate agreement over other contracts of the company; the parties to the contract are only members of the company. The attention is drawn to the conditions under which a corporate contract is worthless. The purpose and motives of the conclusion of a corporate agreement by the members of a limited liability company are described. Particular attention is paid to considering the issue of the validity of the corporate agreement. The peculiarities of consolidation of the prevailing rights of the members of the limited liability company in the content of the corporate agreement are analyzed. Other essential conditions of the corporate agreement are investigated. The discussion points about the confidentiality of the corporate agreement are defined and ways of overcoming them are offered. The peculiarities of the disclosure of a corporate agreement, the party of which is a state, a territorial community, a state or a municipal enterprise or a legal entity, is considered.

The contractual relations arising from the corporate agreement are characterized by dynamism, therefore the members of the limited liability company (parties to the agreement), in cases determined by law, are given the right to change the content of the corporate agreement is proved. The positive aspects of the consolidation of the corporate agreement in the new Law of Ukraine "On Limited Liability Companies" were determined.

Key words: limited liability company, corporate rights, corporate agreement, members in the corporate agreement, term of the corporate agreement, confidentiality of the corporate agreement. 